\title{
Equal Sharing of Domestic Responsibilities as A Mean of Enhancing Woman's Economic Participation in Jordan
}

\author{
Ayman Halaseh $^{1^{*}} \quad$ Hamdi Alqubelat $^{2}$ \\ 1.Associate Professor in Public International Law \& Human Rights, Faculty of Law, Isra University, PO box 33 \\ and 22 Isra University Office 11622.Amman, Jordan \\ 2.Professor in Administrative Law, Faculty of Law, Isra University, PO box 33 and 22 Isra University Office \\ 11622.Amman, Jordan
}

\begin{abstract}
This paper explores how equal sharing of domestic and family responsibilities can have positive impact of women's economic participation in Jordan. Jordanian women's capabilities and potential were manifested during the past three decades in the areas of education and health where women achieved advanced positions and often surpassed men. Nevertheless, this excellence did not reflect on women's engagement in the labour market. Recent statistics indicate that the economic participation of Jordanian women in the labour market lies in its lowest level and this is why national polices and legislation need to be revisited to make the concept of sharing of family and domestic responsibilities between spouses a realistic and viable matter
\end{abstract}

Keywords: Jordan, Women Economic Participation, equal sharing of domestic responsibilities, CEDAW.

DOI: $10.7176 / \mathrm{JLPG} / 86-16$

Publication date: June $30^{\text {th }} 2019$

\section{Introduction}

The concluding observations issued by the Human Rights treaty bodies receive the attention of governments, civil society organizations and national human rights bodies, as they provide the state concerned with a roadmap to take appropriate measures, legislative and non-legislative, to guarantee the implementation of the provisions of the convention and fulfilment of international obligations.

It is natural to be difficult to implement the several recommendations included in the concluding observations; therefore, the government select part of these recommendations and work on implementing them, while the civil society bodies select the other part for purposes of establishing lobbying campaigns and advocacy for purposes of enforcing them. Consequently, a considerable part of these recommendations remains with no follow up of any kind. Amongst this category of recommendations what was provided in the concluding observations in relation to the sixth periodic report of Jordan with respect to the Convention on the Elimination of all Forms of Discrimination Against Women (CEDAW), which recommended to "Promote the equal sharing of family and domestic responsibilities between women and men, including by introducing compulsory paternity or shared parental leave following childbirth". This recommendation came after the Committee on the Elimination of Discrimination Against Women has noted the lack of sufficient measures that promote the concept of sharing of family responsibilities and combat the difficulties that a woman faces in combining work and family responsibilities, a matter that negatively affects her economic participation (CEDAW Committee 2017).

\section{What is meant by the concept of sharing of family and domestic responsibilities}

Article 5 of the Convention on the Elimination of Discrimination Against Women obliges the states to take appropriate measures to modify the social and cultural patterns of conduct of men and women, with the aim to achieve the elimination of prejudices and customary and all other practices which are based on the belief that either sex is inferior or superior to the other, or based on stereotyped roles for men and women; and to ensure that family education includes a proper understanding of maternity as a social function, and the recognition of that upbringing and educating children are common responsibilities of both parents, it being understood that the interest of the children is the primordial consideration in all cases.

From the foregoing, it is noted that sharing of family and domestic responsibilities is part of the requirements of this article, nevertheless, it is one of the means that aim to modify the social patterns and stereotypes and other habits and practices which are based on that one sex is inferior or superior to the other.

Article 5 of the convention is perhaps the least utilized in the developing countries as a means of achieving legal and actual equality between men and women; as emphasis is often placed on the explicit provision of equality within the constitution, matters of personal status, political empowerment, and women's access to equal rights as men in terms of acquiring citizenship and transferring it to their children. Whereas many European countries placed this matter amongst their priorities and so they have adopted strategies and legislations which distribute the rights associated with childcare -also known as rights associated with the working mother, between the father and the mother, such as distributing childcare leave between the working father and mother; 
as following this policy will contribute to increasing the economic participation of women by reducing the wage gap between men and women, and will increase women's chances to take up leadership positions (Council Directive 2010/18/EU)

The language used in this article may be one of the main reasons which explain the developing countries' lack of interest in it; since the implementation mechanism, as per the text [of the article] is limited to the modification of the stereotypes and social roles by taking "appropriate measures" which can take the form of awareness campaigns without taking any administrative measures -executive or legislative, to the contrary of many of the other articles of the convention, for example article 6 which states that "States Parties shall take all appropriate measures, including legislation, to suppress all forms of traffic in women and exploitation of prostitution of women", and article 15(4) which states that "States Parties shall accord to men and women the same rights with regard to the law relating to the movement of persons and the freedom to choose their residence and domicile", and Article 2(a) which states that "To embody the principle of the equality of men and women in their national constitutions or other appropriate legislation. This was affirmed by the legal and interpretive literature on this article until the end of the last century( Holtmaat 2012), which made some criticize the convention as not keeping up with the development that occurred to women's rights globally, and for its inability to address the structural discrimination rooted in a particular society (Mendes \& Srighanthanv2009)

However, the previous position rapidly changed in 2004 when the Committee on the Elimination of Discrimination Against Women issued the general recommendation No. 25 on article 4 and expressly stated that it is amongst the requirements of the obligations of states under the convention to address the gender-based social roles and stereotypes which negatively affect women, through the law and the legal institutions. It is worthwhile to state that this recommendation came in the context of interpreting the scope of application of the temporary special measures with the aim to accelerate actual equality between men and women, meaning that these measures can be resorted to in order to eliminate the stereotypes that diminish women's rights.

\section{The reality of the economic participation of Jordanian women}

The expression "Women Empowerment" emerged in the 1990s through the international conventions concerned with the rights of women. Definitions of this expression and its purpose were centred around the woman's realization of her self-worth and capabilities, and joining active groups in the society to represent women's interest within political and economic decision-making positions, through redistributing the unequal power relations between men and women by promoting women's self-reliance and providing them with power factors and resources which enable them to effect change in the society (Al-Okour 2016).

At the national level, Jordanian women's capabilities and potential were manifested during the past three decades in the areas of education and health where women achieved advanced positions and often surpassed men. Nevertheless, this excellence did not reflect on women's engagement in the labour market (Global Gender Gap Report 2018). Recent statistics indicate that the economic participation of Jordanian women in the labour market lies in its lowest level, ranking $133^{\text {rd }}$ out of 140 countries, as per the Global Competitiveness Report for 2018 (Jordan Strategy Forum Report 2018). The poor economic participation of Jordanian women is deemed as one of the key problems that is facing the national economy; on the one hand, it deprives large productive capacities from contributing towards building and developing the national economy, on the other hand, it increases the dependency ratio in Jordan, which is already among the highest ratios on the global level (Jordan Labour 2018).

Over years, several studies (Stave, 2015 \& Mehtap, 2016) have addressed the reasons for the lack or decline of Jordanian women's economic participation from many respects, with regard to the society and surrounding environment, infrastructure and level of basic services, harassment, wage gap between working men and women, absence of childcare facilities, etc. In addition to the discriminatory stereotypes concerning the roles and responsibilities of women and men in the family and the society, which limit the role of a woman in being a wife and a mother, and on the other hand, undermine her social status, independence, and potential opportunities for education and employment. This was illustrated by the Committee on the Elimination of Discrimination Against Women as it urged Jordan to adopt an urgent comprehensive strategy to achieve gender equality in the area of employment (CEDAW Committee 2017).

\section{Family and domestic responsibilities in Jordanian legislation}

It may be difficult to count the Jordanian legislation relevant to the family and domestic responsibilities in general, however, this section aims to point out how such legislation addressed the family and domestic responsibilities in the event of the employment of either spouse. In this context, several references were made in Jordanian legislation to the family and domestic responsibilities. However, these references are based on granting rights to the woman in the event of her employment based on considering her as the [person] responsible for the childcare, which is a matter the international human rights standards are trying to avoid through the concept of sharing family and domestic responsibilities between spouses; below are the key legislation in that regard: 


\section{1 the Jordanian Constitution}

The Jordanian constitution has always been subject to criticism for not incorporating sex or gender as grounds for non-discrimination under article 6(1) of the constitution. Upon review of the provisions of the constitution, we find that it refers to women in only two instances, these are: under article 23 concerning employment, of which paragraph 2(4) stipulates the necessity to set special conditions for the employment of women and juveniles; and under article 6(5) which states that the law shall protect maternity, childhood and old-age, and support adolescents and persons with disabilities and protect them from abuse and exploitation; noting that [said] paragraph 5 was amongst the amendments made to the constitution in 2011.

Article 6(5) was subject to criticism for not referring to women except in the context of protection of maternity, which promotes the stereotypes about the roles of women and men, their responsibilities and identities in all spheres of life (CEDAW Committee 2012).

With regard to the family, paragraph 4 was added to article 6 in the constitutional amendments of 2011; where it states that the family is the foundation of the society and its mainstays are religion, morality and patriotism, the law safeguards the family's legal existence and reinforces its ties and values.

\section{2 the Personal Status Law}

Under articles 187, 59 \& 61 of the Personal Status law, the husband is obliged to provide alimony (maintenance) for children and wife even if the wife is solvent or employed with his consent. With regard to the upbringing of children, based on article 170 it rests with the mother, who shall have preferential right to custody and upbringing of children during marriage and after separation. According to article 173, the mother shall continue to have custody until the child reaches the age of fifteen years old, custody may continue until the age of majority if the child so chooses, or if [the child] was in need for care by a female due to illness. Accordingly, it can be said that the Personal Status law promotes traditional stereotypes where the husband handles expenditure and the wife handles care and nurturing, which means there is a total absence of the concept of shared family responsibilities, and therefore, placing additional burdens on women due to the difficulty in combining work and family responsibilities.

\subsection{Labour Law}

It is obvious that the Labour law has linked the family and domestic responsibilities associated with childcare to the working mother and not the working father; therefore, we find that the law has dedicated special rights to the working women out of their traditional role; they are as follows:

1- The employment of a working woman may not be terminated on grounds of pregnancy or during maternity leave

Article 27(a) of the Labour law [states that] "Subject to the provisions of paragraph (b) of this article, the employer may not terminate the employment of the employee or serve the employee with a termination notice in any of the following instances:

1. The pregnant working woman, starting from the sixth month of her pregnancy, or during maternity leave".

2- Childcare leave

Article 67 of the Labour law [states that] "The woman, who works at an establishment which employs ten employees or more, shall have the right for a leave without pay for a period of not more than one year to look after her children. She shall have the right to return to her work upon expiry of such leave provided that she will lose this right if she worked against payment at any other establishment during that period".

3- Maternity leave

Article 70 [states that] "The working woman shall have the right for a maternity leave with full pay pre- and post-natal for a duration totalling 10 weeks, provided that the post-natal leave duration is for not less than 6 weeks; and it is prohibited to employ her before the expiry of that duration". It is noted from this article that working woman's maternity leave under the Labour law is less than that under the Civil Service Regulation, which under the latter amounts to 90 days".

4- Nursing hour

Article 71 [states that] "Upon expiry of the maternity leave stipulated under article (70) of this law, the working woman shall be entitled, for one year from the date of childbirth, for paid period(s) not exceeding a total of one hour per day, for purposes of nursing her new-born child".

5- Childcare facilities for the children of working women

Article 72 [states that] "The employer who employs not less than twenty female workers shall provide a suitable place under the care of a qualified child-carer to look after the female workers' children aged less than four years old, provided that the number of children is not less than 10 ". 


\subsection{The Civil Service Regulation}

In spite of that the working mother under the provisions of the Jordanian Civil Service Regulation No. (82) of 2013 falls under the definition of the public officer pursuant to article (2) of the regulation [which defines it as] "The person appointed by a decision taken by a competent authority to any job listed in the manning table issued pursuant to the Public Budget Law or the budget of a certain department, including the officer appointed under a contract, but excluding persons who are paid on daily basis". Accordingly, pursuant to this definition there is no discrimination between male and female workers, in principle. However, the regulation has dedicated special rights to the working mother, they are as follows:

1- Family allowance

Family allowance shall be paid to the female employee if her husband is handicapped or she was the breadwinner for her children, or if she was divorced and is not in receipt of alimony for her children where the latters were at the age of not more than (18) years old (article 25(b)); noting that this case is the exception to the rule which involves discrimination against women as it provides that the family allowance shall be paid to the husband, in principle (article 25(a)).

2- Maternity leave

The pregnant employee is entitled for a consecutive 90-day maternity leave, pre- and post-natal, and with full pay and allowances based on a medical report from a doctor or a midwife; the maternity leave shall not affect the female employee's entitlement for annual leave (article 105(a)).

3- Nursing hour

Upon expiry of the maternity leave stipulated under paragraph (a) of this article, the female employee shall be entitled for one nursing hour per day for the period of 9 months, for purposes of nursing her newborn child, which shall not affect her annual leave, salary and allowance (article 105(c)).

4- Leave without pay (Article 108(a) $(5,6))$ :

The female employee, upon her request, may be granted a leave without pay in the following instances:

- Upon expiry of the maternity leave and for a period of not more than 2 years, for purposes of looking after her baby child, after deducting the period where she was on duty following the expiry of the maternity leave.

- $\quad$ For purposes of spending the legal waiting period after death of her husband, and for the period of not more than 4 months and 10 days.

The approach taken by the Civil Service Regulation is not very different from the approach taken by the Labour law, with some differences such as in the absence of the childcare facilities issue and the difference between the maternity leave under the Labour law and the Civil Service Regulation; however, the main idea is that the working mother enjoys a number of privileges in order to carry out family responsibilities associated with the childcare. And although the Civil Service Regulation has provided for a 2-day paternity leave upon childbirth according to article 105(b), it is still incomparable to the mother's leave, and so it is more of a symbolic nature, not aimed to care for the child, but instead, it is hardly enough to do some formalities such as childbirth registration and issuance of necessary documents.

\section{Rights turn into obstacles}

Several studies confirm that the rights enjoyed by the working mother are among the main reasons that affect her economic participation (World Bank, 2013 \& Phenix Center 2016). For example, when article 72 of the Labour law obliged the employer who employs not less than 20 female workers to provide a suitable place under the care of a qualified child-carer to look after the female workers' children aged less than four years old provided that the number of children is not less than 10, the result was that the employers, intentionally, would not employ more than 19 female workers so they can avoid the obligation to provide childcare facilities. Consequently, this privilege for the working mother has turned into an obstacle in her way to obtain a job. It is the same with regard to the other rights, for example, the right for a leave without pay for a period of not less than two years for working mothers in the public sector may turn into a barrier to her career advancement and appointment in supervisory and leadership positions, in addition, it shortens her career lifetime.

Despite the positive aspects of these rights, it must be admitted that they promote stereotypes and affirm that the woman is responsible for the house and children while the man plays the breadwinner role. This in turn leads to the conclusion that the legislative framework in Jordan does not promote sharing of responsibilities between men and women, but instead, it entrenches the prevailing economic, social and cultural roles in the society. Noting that the international committees and bodies concerned with human rights assert that sharing of responsibility between men and women in all spheres is the most efficient way to achieve actual equality (ESCR Committee, General comment No. 16). And the sharing of family privileges between the working father and working mother shall prevent discrimination against women with regard to their economic participation. 


\section{Conclusion}

The international committees on human rights affirm that the stereotype patterns associated with the gender, and the roles imposed by the society on the father and the mother have an evident effect on women's rights and constitute a barrier to women's enjoyment of their rights on equal terms with men (Biholar 2014). Certainly, the impact of stereotypes varies depending on the rights [themselves], but in terms of women's economic participation, it shows that the stereotypes are entrenched by virtue of law, which makes the prevailing thought that the discriminative stereotypes in relation to the role of women can be eliminated through launching information campaigns with the media to strengthen understanding of actual gender equality, a fruitless process.

Based on the foregoing, we find it necessary to have a legislative intervention that makes the concept of sharing of family and domestic responsibilities between spouses a realistic and viable matter, through:

1. Reviewing the working mother's rights and reclassifying them as family's or child's rights.

2. Amending the provisions related to the rights of working mothers and making them optional to the extent possible to be taken by either parent, such as the maternity leave, and the childcare leave without pay, so they can be distributed between the mother and the father.

3. Reconsidering the paternity leave concept provided under the Civil Service Regulation to make it complementary to the maternity leave, in order to enable the father to participate in the family and domestic responsibilities; in addition to introducing the [paternity leave] concept into the Labour law.

\section{References}

Al-Okour, E. (2016), “Women Economic Empowerment realities and Opportunities", Jordanian Ministry of Labor, Amman - Jordan.

Biholar, R., (2014), "Challenging the Barriers to Real Equality: Transformative Equality", Annual Gathering of the Group of Women Parliamentarians, Moving from Formal to Substantive Equality, Mexico City, Mexico

Committee on Economic, Social and Cultural Rights. (2005), General comment No. 16, The equal right of men and women to the enjoyment of all economic, social and cultural rights, E/C.12/2005/4.

Committee on the Elimination of Discrimination against Women (2012), Concluding observations on the sixth periodic report of Jordan, CEDAW/C/JOR/CO/5,

Committee on the Elimination of Discrimination against Women (2017), Concluding observations on the sixth periodic report of Jordan, CEDAW/C/JOR/CO/6.

European Commission: DIRECTIVE OF THE EUROPEAN PARLIAMENT AND OF THE COUNCIL on work-life balance for parents and careers and repealing Council Directive. (2017), 2010/18/EU, Brussels, 26.4.2017, $\mathrm{COM}(2017) 253$ final.

General recommendation No. 25, on article 4, paragraph 1, of the Convention on the Elimination of All Forms of Discrimination against Women, on temporary special measures

Holtmaat, R. (2012), "'Article 5 CEDAW" in: Marsha A. Freeman, Christine Chinkin \& Beate Rudolf (eds.), The Convention on the Elimination of All Forms of Discrimination against Women: A Commentary (Oxford: University Press), $141-167$.

Jordan Labour Watch/Phenix Center for Economic and Informatics Studies in association with Friedrich Ebert Stiftung. (2018), “Women's Economic Participation in Jordan remains weak”, Amman - Jordan.

Jordan Strategy Forum Report. (2018), "Jordan on the Global Competitiveness Index 2018 - Opportunities and Challenges", Amman - Jordan.

Mehtap, S., Jayyousi, Y., Gammoh, N., Al Haj, A., (2016), "Factors Affecting Women's Participation in the Jordanian Workforce", International Journal of Social Science and Humanity 6(10), p 790-793.

Mendes, E. P., \& Srighanthan, S. (2009), "Confronting Discrimination and Inequality in China: Chinese and Canadian Perspectives", Les Presses de l'Université d'Ottawa | University of Ottawa Press. Retrieved from http://books.openedition.org/uop/1134

Phenix Center for Economics and Informatics Studies. (2016), “Women's Economic Participation in Jordan: Reality and Challenges of the Private Sector", PRIME Issues Paper, Amman - Jordan.

Stave, E., Kattaa, M. (2015), "Labour force and unemployment trends among Jordanians, Syrians and Egyptians in Jordan 2010-2014", ILO and Fafo Institute for Applied International Studies

World Bank. (2013), Jordan Country Gender Assessment: Economic Participation, Agency and Access to Justice in Jordan

World Economic Forum. (2018), The Global Gender Gap Index 